\title{
集中衝撃移動荷重を受ける 弾性基礎上の厚板の過渡波動伝播解析
}

\author{
石川清志 ${ }^{1}$ 依田照彦 2 ・平嶋政治 ${ }^{3}$ \\ ${ }^{1}$ 正会員 工博 信州大学技官 工学部社会㲦発工学科 (广 380 長野市若里 500 ) \\ ${ }^{2}$ 正会員 工博 早稻田大学数授理工学部土木工学科 ( 169 東京都新宿区大久保 3-4-1) \\ ${ }^{3}$ 正会員 工博 早稻田大学名誉教授理工学部土木工学科 ( 169 東京都新宿区大久保 3-4-1)
}

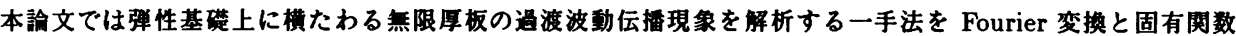
を用いて提案している. 基楚からの反力は基楚に接する厚板底面の变位に比例するといj Winklerの仮定を用 いた．静止している厚板の表面に集中荷重が䈏的に負荷され，直ちに定速度で移動する同題を取り上げ，载 荷点から少し離れた厚板内のある一空间点に注目し，静止から最初の波面到達によって引き起こされる初期の 摄乱，ならびに後糛到達する波動の伝播速度，伝播経路等の透いによって誘起される摄乱を境界での反射現象 と関連つけて明らかにした.
\end{abstract}

Key Words : transient waves, thick plate, reflection, elastic foundation, eigenfunctions, moving loads

\section{1. まえがき}

弾性基礎上の板の曲げ解析には基礎を Winkler 弾 性基礎と考えるすの，半無限弾性体と考えるすのに分 けられる. 前者は粘弾性基礎, 弾塑性基礎への拡張が 容易であるが, 解析に用いる基碳弾性係数 (foundation modulus) の決定が難しいとされる1). とくに動的問題 では，基礎体の慣性効果を考虑できないことや，自由 縁を有する板などに現れる, 時間変化の振動による局 部的浮き上がりによる負反力の扱い方などに課題が残 されている. 一方, 後者はより精密な解析であるるの

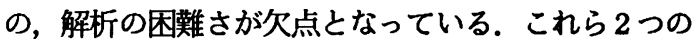
考え方と別なものとしては, 梁の曲げ振動問題ではあ るが，基礎は縦振動するロッドの集合体とみなし，梁 の曲げたわみと基礎の縦振動変位を連成させ, 基礎の 慣性効果をる考虑しようとする研究2) あある.

半無限体上の表面層 (あるいは厚板) の問題におい て, Love の表面波は, Rayleigh 波と異なり分散性を有 し, 半無限体の横波伝播速度が表面層のそれより大き い場合に, はじめてこの表面波は存在する. 半無限体, 表面層の横波伝播速度はそれぞれの横弾性係数, 密度 に関係することから, 半無限体の弾性係数が表面首の あのと比較して近いか， あるいは小さい場合には Love の表面波の問題として扱うことが困難となる3).このよ うなことから，比較的軟弱な基礎上にある厚板など，基 礎の弾性係数が厚板のものと比較して小さい場合には Love の表面波の問題として扱うことか難しいことにな る.このような場合, 軟弱基礎を Winkler 弾性基礎と
仮定するならば，境界条件の扱い方で 2 層問題が 1 層 の問題に置き変わり解析は簡単になる．また基礎をバ ネで置き換えることにより解析の適用範囲が広くなる.

移動荷重を受ける 2 次元動的問題は最初 $\mathrm{Lamb}^{4)}$ に よって定式化され，その後 Sneddon ${ }^{5)}, \mathrm{Cole}^{6)}$ らによっ て発展された. それらは線荷重が一定速度で弾性半空 間上を移動する問題を対象にしており, 荷重が加えら れ，移動し始めてから十分時間が経過した後の定常応 答を調べたすのである. それ故, 載荷の瞬間には弾性波 が発生するすのの，はじめの擾乱の伝播にはふれてい ない.これらは古典弾性学の問題に属するが, 移動荷 重の研究は核爆発の圧力波に基づく地壳の挙動を明ら かにするうえで工学上きわめて重要であるとして, 当 時多くの注目を集めだ).

移動荷重を受ける 2 次元動的問題の解析は意外と少 なく, Gakenheimer ${ }^{8)}$ らは半無限体上を集中荷重が一定 速度で移動する問題を変位ポテンシャル理論に基づく 波動方程式の解, ならびに時間变数消去に Laplace 変

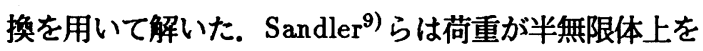
Rayleigh 波伝播速度で移動する問題を扱い，移動荷重 の直前に生じる応力の特異性について論じた。

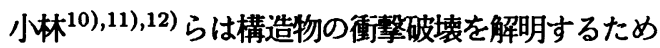
に，衝撃荷重を受ける合成梁などの問題を精密に解い た. その中で衝撃問題では一般となっている時間変数 消去の Laplace 変換より, 固有関数による解法の有用 性を指摘している.

本研究は過渡波動伝播解析 ${ }^{13), 14)}$ をさらに発展させ るすので, 2 次元動的問題における一般的解法である, 


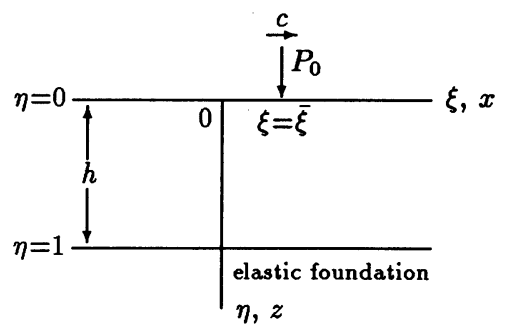

目-1 弾性基礎上の無限厚板

波動方程式を基本解とする変位ポテンシャル理論と時 間変数消去の Laplace 変換 ${ }^{15), 16)}$ を用いずに, Fourier 変換之固有関数を用いて, 連立偏微分方程式で表され た運動方程式が境界条件, 初期条件のもとで直接的に, しかも精密に解かれる方法を提案する. 解析の対象と しては，着陸衝撃を受ける地盤上滑走路の舗装盤，爆 発による移動圧力波を受ける海面の水などの衝擊応答 を解明するために，弾性基礎上の厚板表面に集中衝撃 移動荷重を受けた場合, 荷重の移動速度と載荷直後か ら誘発される擾乱の伝播に注目し，境界での反射現象 を含めて厚板内の過渡波動伝播現象を調べる。

\section{2. 運動方程式，境界条件，および初期条件}

均質等方弾性体における変位を未知関数とした運動 方程式 (Navier の式) は次のように表される.

$$
\mu\left[\nabla^{2} u+(1+b) \operatorname{grad} \operatorname{div} u\right]=\varrho \frac{\partial^{2} u}{\partial t^{2}}, \quad b=\frac{\lambda}{\mu}
$$

ここに, $\boldsymbol{u}$ は変位ベクトル, $\nabla^{2}$ は Laplace 演算子, $\lambda$, $\mu$ は Lamé の弾性係数, $\varrho$ は質量密度, $t$ は時間であ る.ここでは直交座標 $(x, y, z)$ に依存する変位べクト ルを $\boldsymbol{u}=\left(u_{x}, u_{y}, u_{z}\right)$ とし, 問題を簡単化するために 2 次元平面ひずみ問題 $\left(\partial u_{y} / \partial y=0\right)$ とする.

いま, 弾性基礎上に厚さ $h$ の無限厚板が $x$ 方向に 横たわっている問題 (図一-1) を考える. 荷重は便宜, 分 布直荷重 $p_{z}$ とし，厚板の自由表面境界 $z=0$ の一部分 に作用するすのとする.これより境界条件は

$$
x \rightarrow \pm \infty:\left(u_{x}, u_{z}, \frac{\partial u_{x}}{\partial x}, \frac{\partial u_{z}}{\partial z}, \text { etc. }\right)=0
$$

および

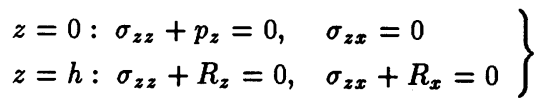

となる. 式(2) は $x \rightarrow \pm \infty$ で変位, 応力がゼロを表す。 ここで, $\sigma_{j k}(j=x, z, k=x, z)$ は応力, $R_{x}, R_{z}$ はそれぞ れ $x, z$ 方向の基礎からの反力である. 反力と変位の関 係は Winkler の仮定 ${ }^{17)}$ を用いれば，次式

$$
R_{x}=k_{x} u_{x}(x, h, t), \quad R_{z}=k_{z} u_{z}(x, h, t)
$$

で与えられる. $k_{x}, k_{z}$ は基礎弾性係数で, 值の取り方に よっては比較的軟弱な基礎をも含めるかたちで, 応力自 由から変位固定までの中間的な境界を扱える. Winkler の仮定は問題の定式化が容易であるので採用した。

初期条件は静止を与える.すなわち，

$$
t=0: u_{x}=u_{z}=0, \frac{\partial u_{x}}{\partial t}=\frac{\partial u_{z}}{\partial t}=0
$$

解析を容易にするために，次の無次元座標

$$
\xi=\frac{x}{h}(|\xi|<\infty), \quad \eta=\frac{z}{h}(0<\eta<1)
$$

および無次元時間

$$
\tau=\frac{c_{T} t}{h}(0<\tau), \quad c_{T}=\sqrt{\mu / \varrho}
$$

を導入する. $c_{\boldsymbol{T}}$ は横波の伝播速度である. このとき 2 次元平面ひずみ問題の運動方程式は次式で表される.

$$
\begin{aligned}
& \nabla^{2} u+(1+b) \frac{\partial \theta}{\partial \xi}=\frac{\partial^{2} u}{\partial \tau^{2}}, \\
& \nabla^{2} w+(1+b) \frac{\partial \theta}{\partial \eta}=\frac{\partial^{2} w}{\partial \tau^{2}}
\end{aligned}
$$

ここに,

$$
u=\frac{u_{x}}{h}, \quad w=\frac{u_{z}}{h}, \quad \nabla^{2}=\frac{\partial^{2}}{\partial \xi^{2}}+\frac{\partial^{2}}{\partial \eta^{2}}, \quad \theta=\frac{\partial u}{\partial \xi}+\frac{\partial w}{\partial \eta}
$$

なお, $u, w$ は無次元变位である. 無次元応力

$$
\begin{aligned}
& \sigma_{\eta \eta}=\frac{\sigma_{z z}}{\mu}=(2+b) \frac{\partial w}{\partial \eta}+b \frac{\partial u}{\partial \xi}, \\
& \sigma_{\eta \xi}=\frac{\sigma_{z x}}{\mu}=\frac{\partial w}{\partial \xi}+\frac{\partial u}{\partial \eta} \\
& \sigma_{\xi \xi}=\frac{\sigma_{x x}}{\mu}=(2+b) \frac{\partial u}{\partial \xi}+b \frac{\partial w}{\partial \eta}
\end{aligned}
$$

を用いれば，境界条件は

$$
\xi \rightarrow \pm \infty:\left(u, w, \frac{\partial u}{\partial \xi}, \frac{\partial w}{\partial \eta}, \text { etc. }\right)=0
$$

および

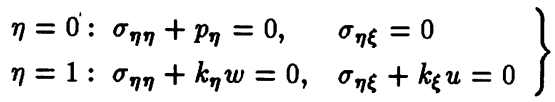

と書き換えられる.ここに,

$$
p_{\eta}=\frac{p_{z}}{\mu}, \quad k_{\eta}=\frac{k_{z} h}{\mu}, \quad k_{\xi}=\frac{k_{x} h}{\mu}
$$

初期条件は単に次式となる。

$$
\tau=0: u=w=0, \frac{\partial u}{\partial \tau}=\frac{\partial w}{\partial \tau}=0
$$

\section{Fourier 変換}

関数 $S(\xi)$ の Fourier 変換は次式で定義される ${ }^{5)}$.

$$
\tilde{S}(\gamma)=\int_{-\infty}^{\infty} S(\xi) e^{-i \gamma \xi} d \xi
$$

その逆変換は

$$
\begin{aligned}
S(\xi) & =\frac{1}{2 \pi} \int_{-\infty}^{\infty} \tilde{S}(\gamma) e^{i \gamma \xi} d \gamma \\
& =\frac{1}{2 \pi} \int_{0}^{\infty}\left[\tilde{S}(-\gamma) e^{-i \gamma \xi}+\tilde{S}(\gamma) e^{i \gamma \xi}\right] d \gamma
\end{aligned}
$$


で表される. だたし， $i^{2}=-1, \gamma$ は積分変数である. 運 動方程式 (8) を Fourier 変換し, 境界条件 (11) で解け ば次式が得られる。

$$
\begin{aligned}
& \frac{\partial^{2} \tilde{u}}{\partial \eta^{2}}-\gamma^{2}(2+b) \tilde{u}+i \gamma(1+b) \frac{\partial \tilde{w}}{\partial \eta}=\frac{\partial^{2} \tilde{u}}{\partial \tau^{2}}, \\
& (2+b) \frac{\partial^{2} \tilde{w}}{\partial \eta^{2}}-\gamma^{2} \tilde{w}+i \gamma(1+b) \frac{\partial \tilde{u}}{\partial \eta}=\frac{\partial^{2} \tilde{w}}{\partial \tau^{2}}
\end{aligned}
$$

応力の Fourier 変換が

$$
\begin{aligned}
& \tilde{\sigma}_{\eta \eta}=(2+b) \frac{\partial \tilde{w}}{\partial \eta}+i \gamma b \tilde{u}, \quad \tilde{\sigma}_{\eta \xi}=\frac{\partial \tilde{u}}{\partial \eta}+i \gamma \tilde{w}, \\
& \tilde{\sigma}_{\xi \xi}=b \frac{\partial \tilde{w}}{\partial \eta}+i \gamma(2+b) \tilde{u}
\end{aligned}
$$

と表されることから, 境界条件 (12) は次式となる.

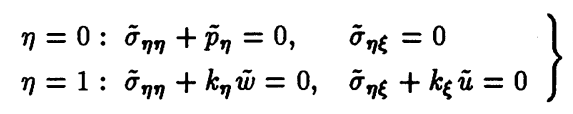

いま，集中荷重 $P_{0}$ が $\xi=\bar{\xi}$ 点に作用している場合を考 えると, $\tilde{p}_{\eta}$ は次式で表される.

$$
\tilde{p}_{\eta}=P_{0} e^{-i \gamma \bar{\xi}}
$$

さらに, $P_{0}$ が厚板の表面 $(\eta=0)$ に沿って $\xi$ の正の方 向に一定速度で移動する場合, 時刻 $\tau$ の荷重作用点の 位置 $\bar{\xi}$ は次式となる。

$$
\bar{\xi}=c \tau+\bar{\xi}_{0}
$$

ここに, $c$ は移動速度係数, $\bar{\xi}_{0}$ は初期作用点である.こ こでは載荷直後の過渡現象, すなわち, はじめの擾乱 の伝播に注目していることから, 定常応答問題でよく 使われる Galilei 変換による移動座標7) は用いない. 初 期条件む Fourier 変換し次式で表す.

$$
\tau=0:\left[\begin{array}{c}
\tilde{u} \\
\tilde{w}
\end{array}\right]=\frac{\partial}{\partial \tau}\left[\begin{array}{c}
\tilde{u} \\
\tilde{w}
\end{array}\right]=0
$$

\section{4. 固有関数による級数展開}

連立偏微分方程式で表された運動方程式 (17) を境 界条件 (19), 初期条件 (22) で解くにあたり，ここで は Stokes の方法による固有関数解析 ${ }^{18), 19)}$ を導入する. Fourier 変換された変位 $\tilde{u}, \tilde{w}$ は

$$
\left[\begin{array}{c}
\tilde{u} \\
\tilde{w}
\end{array}\right]=\sum_{m=1}^{\infty} A_{m}(\tau)\left[\begin{array}{l}
\phi_{m}(\eta) \\
\psi_{m}(\eta)
\end{array}\right]
$$

と仮定する.ただし, $A_{m}$ は末知関数, 関数 $\phi_{m}, \psi_{m}$ は変位の座標関数を表すすので次の連立常微分方程式

$$
\begin{gathered}
\frac{d^{2} \phi_{m}}{d \eta^{2}}-\gamma^{2}(2+b) \phi_{m}+i \gamma(1+b) \frac{d \psi_{m}}{d \eta}=-\omega_{m}^{2} \phi_{m}, \\
(2+b) \frac{d^{2} \psi_{m}}{d \eta^{2}}-\gamma^{2} \psi_{m}+i \gamma(1+b) \frac{d \phi_{m}}{d \eta}=-\omega_{m}^{2} \psi_{m}
\end{gathered}
$$

を満足するすのである．ただし， $\omega_{m}$ は任意定数であ る. 式(23) を式 (18) に代入すると応力は

$$
\left[\begin{array}{c}
\tilde{\sigma}_{\eta \eta} \\
\tilde{\sigma}_{\eta \xi} \\
\tilde{\sigma}_{\xi \xi}
\end{array}\right]=\sum_{m=1}^{\infty} A_{m}(\tau)\left[\begin{array}{c}
\Psi_{m}(\eta) \\
\Phi_{m}(\eta) \\
\Theta_{m}(\eta)
\end{array}\right]
$$

で表される. $\Psi_{m}, \Phi_{m}, \Theta_{m}$ は応力の座標関数であり, それぞれ次式で表される。

$$
\begin{aligned}
& \Psi_{m}=(2+b) \frac{d \psi_{m}}{d \eta}+i \gamma b \phi_{m}, \quad \Phi_{m}=\frac{d \phi_{m}}{d \eta}+i \gamma \psi_{m}, \\
& \Theta_{m}=b \frac{d \psi_{m}}{d \eta}+i \gamma(2+b) \phi_{m}
\end{aligned}
$$

これより，式(19)を考虑すれば，方程式(24)に対する 境界条件は次式を与えることになる。

$$
\left.\begin{array}{ll}
\eta=0: \Psi_{m}=0, & \Phi_{m}=0 \\
\eta=1: \Psi_{m}+k_{\eta} \psi_{m}=0, & \Phi_{m}+k_{\xi} \phi_{m}=0
\end{array}\right\}
$$

仮定した式 (24) を考察すれば, これはすとの運動方程 式(17) に対して, $\tilde{u}=\phi_{m}(\eta) e^{i \omega_{m} \tau}, \tilde{w}=\psi_{m}(\eta) e^{i \omega_{m} \tau}$ と 変数分離したすのに相当する. これは無限厚板の自由 振動方程式と同じであり， $\omega_{m}$ は円振動数と見ることす できる. また, 式(27) はもとの境界条件 (19) と比較し て, 荷重項が省略されていることになる.

式 (24) の連立常微分方程式と式 (27) の境界条件を 満足する $\phi_{m}, \psi_{m}$ には次の直交性の条件が成立する.

$$
\int_{0}^{1}\left(\phi_{k} \phi_{l}-\psi_{k} \psi_{l}\right) d \eta=0, \quad \omega_{k} \neq \omega_{l}
$$

連立常微分方程式に対する関数の直交性の条件の誘導 は, Dolph ${ }^{20)}$ が Timoshenko 梁理論に適用した方法を 応用した. 式(28)を使えば, 式(23)の $A_{m}$ は次式で 得られる.

$$
A_{m}=\frac{1}{g_{m}} \int_{0}^{1}\left(\tilde{u} \phi_{m}-\tilde{w} \psi_{m}\right) d \eta, \quad g_{m}=\int_{0}^{1}\left(\phi_{m}^{2}-\psi_{m}^{2}\right) d \eta
$$

運動方程式 (17) において, 左辺項をまとめて次の 級数で表すことを考える.

$$
\begin{aligned}
& {\left[\begin{array}{l}
\frac{\partial^{2} \tilde{u}}{\partial \eta^{2}}-\gamma^{2}(2+b) \tilde{u}+i \gamma(1+b) \frac{\partial \tilde{w}}{\partial \eta} \\
(2+b) \frac{\partial^{2} \tilde{w}}{\partial \eta^{2}}-\gamma^{2} \tilde{w}+i \gamma(1+b) \frac{\partial \tilde{u}}{\partial \eta}
\end{array}\right]} \\
& \quad=\sum_{m=1}^{\infty} B_{m}(\tau)\left[\begin{array}{l}
\phi_{m}(\eta) \\
\psi_{m}(\eta)
\end{array}\right]
\end{aligned}
$$

ただし， $B_{m}$ は未知関数である. 同様に, 右辺項もま とめて表すことにすれば，これは式(23) から単に

$$
\frac{\partial^{2}}{\partial \tau^{2}}\left[\begin{array}{c}
\tilde{u} \\
\tilde{w}
\end{array}\right]=\sum_{m=1}^{\infty} \frac{d^{2} A_{m}}{d \tau^{2}}\left[\begin{array}{l}
\phi_{m}(\eta) \\
\psi_{m}(\eta)
\end{array}\right]
$$

となる.このことが成立するならば, 連立偏微分方程 式(17) は, 変数 $\eta$ が共通に消去され，しかす連立性む 解除されて次の時間のみの常微分方程式

$$
B_{m}=\frac{d^{2} A_{m}}{d \tau^{2}}
$$


に引き下げられる. $B_{m}$ は式 (28) の直交性の条件, 式 (24) および (29) の関係を使えば

$$
B_{m}=\frac{1}{g_{m}}\left[\tilde{\sigma}_{\eta \xi} \phi_{m}-\tilde{\sigma}_{\eta \eta} \psi_{m}-\tilde{u} \Phi_{m}+\tilde{w} \Psi_{m}\right]_{0}^{1}-\omega_{m}^{2} A_{m}
$$

と表され，境界条件 (19)，(27)を適用すれば次式となる.

$$
B_{m}=-\frac{\psi_{m}(0)}{g_{m}} \tilde{p}_{\eta}-\omega_{m}^{2} A_{m}
$$

これよ゙り, 式(32)の方程式は次式に置き変わる.

$$
\frac{d^{2} A_{m}}{d \tau^{2}}+\omega_{m}^{2} A_{m}=-H_{m}(\tau)
$$

ここに,

$$
H_{m}(\tau)=\frac{\psi_{m}(0)}{g_{m}} \tilde{p}_{\eta}=P_{0} \frac{\psi_{m}(0)}{g_{m}} e^{-i \gamma\left(c \tau+\bar{\xi}_{0}\right)}
$$

微分方程式 (34) に対する初期条件は式 (22), (23) のか たちから

$$
\tau=0: A_{m}=\frac{d A_{m}}{d \tau}=0
$$

を与えることになる.これによって式(34) は解かれて, $A_{m}$ が次のように決定される.

$$
\begin{aligned}
A_{m} & =-\frac{1}{\omega_{m}} \int_{0}^{\tau} H_{m}\left(\tau^{\prime}\right) \sin \omega_{m}\left(\tau-\tau^{\prime}\right) d \tau^{\prime} \\
& =P_{0} e^{-i \gamma \bar{\xi}_{0}}\left[K_{m}^{e}(\tau)+i K_{m}^{o}(\tau)\right]
\end{aligned}
$$

ここに,

$$
\begin{aligned}
& K_{m}^{e}(\tau)=\frac{\psi_{m}(0)}{g_{m}\left(\gamma^{2} c^{2}-\omega_{m}^{2}\right)}\left(\cos \gamma c \tau-\cos \omega_{m} \tau\right), \\
& K_{m}^{o}(\tau)=\frac{\psi_{m}(0)}{g_{m}\left(\gamma^{2} c^{2}-\omega_{m}^{2}\right)}\left(\gamma c \frac{\sin \omega_{m} \tau}{\omega_{m}}-\sin \gamma c \tau\right)
\end{aligned}
$$

なお， $K_{m}^{e}$ は $\gamma$ に関して偶関数， $K_{m}^{\circ}$ は奇関数となる.

\section{5. 固有関数の決定}

連立常微分方程式 (24) を境界条件 (27) で解けば, $\phi_{m}, \psi_{m}$ が決定され, この問題は解決される. 式 (24) において, $\psi_{m}$ を消去して, $\phi_{m}$ について解けば次式

$$
\square_{1} \square_{2} \phi_{m}=0
$$

が得られる. 逆に, $\phi_{m}$ を消去して, $\psi_{m}$ について解 けば

$$
\square_{1} \square_{2} \psi_{m}=0
$$

を得る.ここで, $\square_{1} \square_{2}$ は $\eta$ に関する 4 階の微分演算子

$$
\square_{1} \square_{2}=\left[\frac{d^{2}}{d \eta^{2}}-\gamma^{2}+\frac{\omega_{m}^{2}}{V_{L}^{2}}\right]\left[\frac{d^{2}}{d \eta^{2}}-\gamma^{2}+\frac{\omega_{m}^{2}}{V_{T}^{2}}\right]
$$

である. ただし, $V_{L}, V_{T}$ は無次元縦波, 横波の伝播速 度であり，それぞれ次式で表される。

$$
V_{L}=\sqrt{2+b}, \quad V_{T}=1
$$

式(39), (40) で得られた方程式は变位ポテンシャル理論 における Galerkin ベクトルの波動方程式7) と同じ内容
を表す。これらの方程式の解は，例えば $\gamma>\omega_{m} / V_{T}$ の とき, 次式で表される.

$$
\begin{aligned}
& \phi_{m}=i\left[\begin{array}{llll}
\cosh \alpha_{m} \eta & \sinh \alpha_{m} \eta & \cosh \beta_{m} \eta & \sinh \beta_{m} \eta
\end{array}\right] N_{m}^{1}, \\
& \psi_{m}=\left[\begin{array}{llll}
\sinh \alpha_{m} \eta & \cosh \alpha_{m} \eta & \sinh \beta_{m} \eta & \cosh \beta_{m} \eta
\end{array}\right] N_{m}^{2}
\end{aligned}
$$

ここに,

$$
\alpha_{m}=\sqrt{\gamma^{2}-\omega_{m}^{2} / V_{L}^{2}}, \quad \beta_{m}=\sqrt{\gamma^{2}-\omega_{m}^{2} / V_{T}^{2}}
$$

$N_{m}^{j}(j=1,2)$ は $4 \times 1$ の列ベクトルで表される積分定 数，〈…」は行べクトルを意味する.これらの解は式 (24) の連立方程式に対してそれぞれ独立となるか， あ るいはなんらかの関係が存在するか調べる必要がある. そのため，これらの解を式 (24) の第 1 式に代入し，解 の各項ごとにまとめると, $N_{m}^{1}$ と $N_{m}^{2}$ との間で次の 関係

$$
\boldsymbol{N}_{m}^{2}=\left[\begin{array}{llll}
\frac{\alpha_{m}}{\gamma} & & & \\
& \frac{\alpha_{m}}{\gamma} & & \\
& & \frac{\gamma}{\beta_{m}} & \\
& & & \frac{\gamma}{\beta_{m}}
\end{array}\right] \boldsymbol{N}_{m}^{1}
$$

が得られる. 式(43)を式(24)の第 2 式に代入してあ同 じ結果が得られる. 式 (45) を式 (43) の第 2 式に代入 し, $\phi_{m}$ の解之併せて調整すると, 次式が得られる.

$$
\begin{aligned}
& {\left[\begin{array}{c}
\phi_{m} \\
\psi_{m}
\end{array}\right]=\left[\begin{array}{c}
i \\
1
\end{array}\right]\left[\begin{array}{cc}
\gamma \cosh \alpha_{m} \eta & \gamma \sinh \alpha_{m} \eta \\
\alpha_{m} \sinh \alpha_{m} \eta & \alpha_{m} \cosh \alpha_{m} \eta
\end{array}\right.} \\
& \left.\begin{array}{cc}
\beta_{m} \cosh \beta_{m} \eta & \beta_{m} \sinh \beta_{m} \eta \\
\gamma \sinh \beta_{m} \eta & \gamma \cosh \beta_{m} \eta
\end{array}\right] \boldsymbol{N}_{m}
\end{aligned}
$$

ここに, $\boldsymbol{N}_{m}$ は新しい $4 \times 1$ の積分定数である. なお, $\gamma>\omega_{m} / V_{T}$ 以外の解は式(44)を考慮すれば, cosh, sinh $\rightarrow \cos$, sin などに変わるだけで対応できる. 結局, こ のようにして得られた解は連立常微分方程式 (24)の一 般解を表す。これらを式 (26) に代入すれば $\Psi_{m}, \Phi_{m}$, $\Theta_{m}$ が得られ，すべて $N_{m}$ に従属して表される。

$N_{m}$ は境界条件 (27) によって決定され，併せて $\omega_{m}$ あ求められる. まず, 境界条件 (27) の第 1 式から, $N_{m}$ は2 個の次元数を減じて $2 \times 1$ で表される積分定数 $M_{m}$ に従属して表される。

$$
N_{m}=L_{m} M_{m}
$$

ここに, $\boldsymbol{L}_{m}$ は $4 \times 2$ の矩形マトリックスである.

$$
\boldsymbol{L}_{m}=\left[\begin{array}{cc}
-2 \gamma \beta_{m} & 0 \\
0 & q_{m} \\
q_{m} & 0 \\
0 & -2 \gamma \alpha_{m}
\end{array}\right], \quad q_{m}=\beta_{m}^{2}+\gamma^{2}
$$

つづいて，境界条件 (27) の第 2 式から次の方程式

$$
B_{m} N_{m}=0
$$




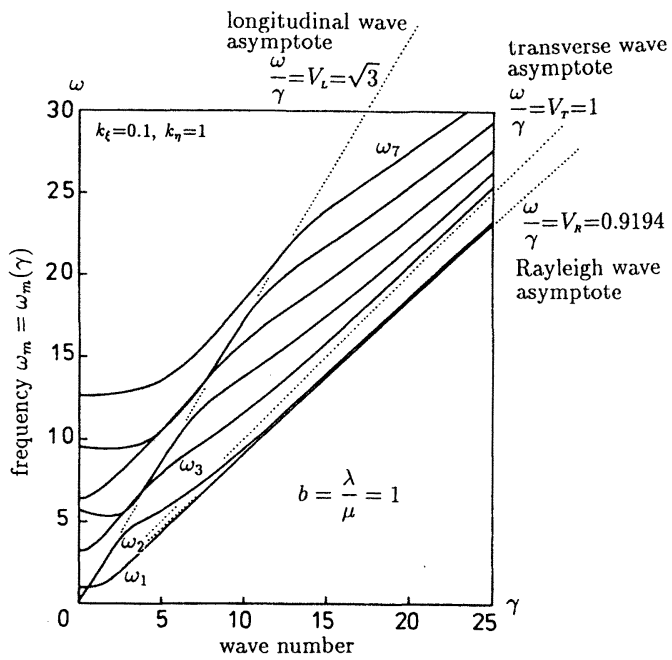

(A) $k_{\xi}=0.1, k_{\eta}=1$

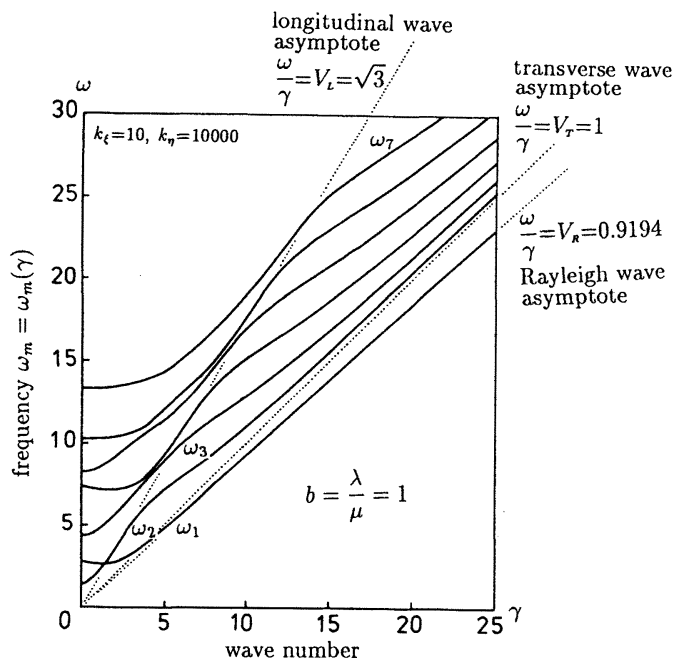

(B) $k_{\xi}=10, k_{\eta}=10000$

园-2 $\gamma$ に依存した固有值方程式の根 $\omega_{m}$

が得られる. $\boldsymbol{B}_{m}$ は $2 \times 4$ の矩形マトリックスである.

$\boldsymbol{B}_{m}=\left[\begin{array}{c}\gamma\left(2 \alpha \sinh \alpha+k_{\xi} \cosh \alpha\right) \\ q \cosh \alpha+k_{\eta} \alpha \sinh \alpha\end{array}\right.$

$\gamma\left(2 \alpha \cosh \alpha+k_{\xi} \sinh \alpha\right) \quad q \sinh \beta+k_{\xi} \beta \cosh \beta$

$q \sinh \alpha+k_{\eta} \alpha \cosh \alpha \quad \gamma\left(2 \beta \cosh \beta+k_{\eta} \sinh \beta\right)$

$$
\left.\begin{array}{c}
q \cosh \beta+k_{\xi} \beta \sinh \beta \\
\gamma\left(2 \beta \sinh \beta+k_{\eta} \cosh \beta\right)
\end{array}\right]_{m}
$$

式(47)を式(49)に代入すると次の方程式

$$
\left[\begin{array}{ll}
Z_{11} & Z_{12} \\
Z_{21} & Z_{22}
\end{array}\right] M_{m}=0
$$

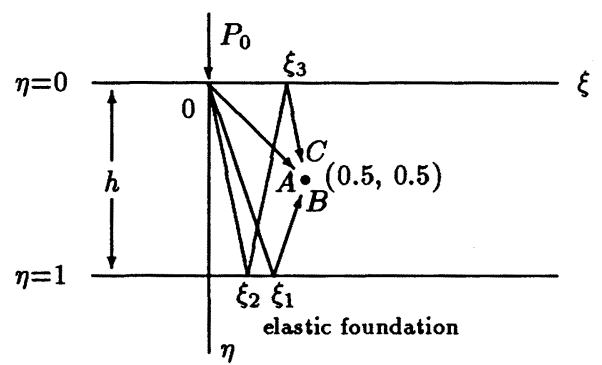

因-3 注目点を通る载荷点で誘発された波動の伝播経路

が得られる. ただし, $Z_{11}, Z_{12}, Z_{21}, Z_{22}$ は

$$
\left[\begin{array}{ll}
Z_{11} & Z_{12} \\
Z_{21} & Z_{22}
\end{array}\right]=B_{m} L_{m}
$$

と得られる. 式(51)では $M_{m} \neq 0$ であるから,

$$
Z_{11} Z_{22}-Z_{12} Z_{21}=0
$$

でなければならない.このことにより式 (51)を満足す る $\boldsymbol{M}_{\boldsymbol{m}}$ は次式で決定される.

$$
M_{m}=\left[\begin{array}{c}
-Z_{12} \\
Z_{11}
\end{array}\right]
$$

この結果と式(47) から $N_{m}$ が決定され， $\phi_{m}, \psi_{m}, \Psi_{m}$ ， $\Phi_{m}, \Theta_{m}$ が求められる. すでに $A_{m}$ が決定されている ので, Fourier 変換された変位, 応力が式(23), (25) に よって得られる. 後は Fourier 逆変換によって変位, 応 力が求められる.

式 (53) は固有值方程式であり, $\gamma$ に依存する固有 值, すなわち式(53) の根 $\omega_{m}$ を求めることになる. し たがって, $\omega_{m}$ は $\gamma$ の関数 $\omega_{m}=\omega_{m}(\gamma)$ として得られ る. 固有值方程式 (53) を詳しく調べると，それは $\gamma$ に 関して偶関数として表され，この結果， $0 \leq \gamma<\infty の$ 範囲で固有值を求めることになる。

式(17) から明らかなように, $\gamma=0$ の特別な場合は $\tilde{u}$ と $\tilde{w}$ とが連成しない. したがって,この場合にはそ れぞれの式が独立に解かれ解析は簡単になる.

\section{Fourier 逆変换}

以上をまとめると Fourier 変換された変位, 応力は

$$
\left[\begin{array}{c}
\tilde{u} \\
\tilde{w} \\
\tilde{\sigma}_{\eta \eta} \\
\tilde{\sigma}_{\eta \xi} \\
\tilde{\sigma}_{\xi \xi}
\end{array}\right]=P_{0} \sum_{m=1}^{\infty}\left[K_{m}^{e}(\tau)+i K_{m}^{o}(\tau)\right]\left[\begin{array}{c}
i \gamma \phi_{m}^{*}(\eta) \\
\psi_{m}(\eta) \\
\Psi_{m}(\eta) \\
i \gamma \Phi_{m}^{*}(\eta) \\
\Theta_{m}(\eta)
\end{array}\right]
$$$$
x e^{-i \gamma \bar{\xi}_{0}}
$$ 

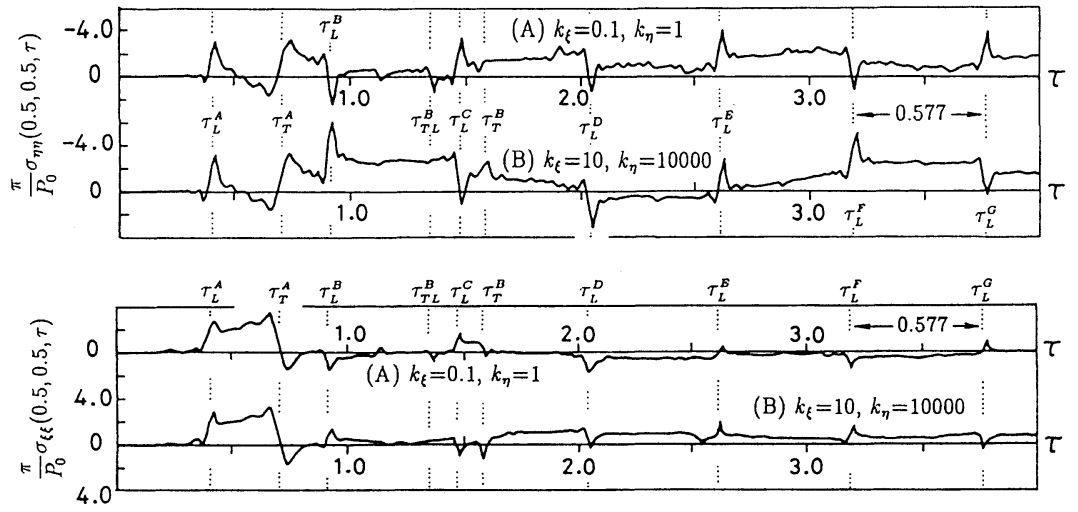

因-4 $c=0$ とした $\sigma_{\eta \eta}(0.5,0.5, \tau), \sigma_{\xi \xi}(0.5,0.5, \tau)$ の応答

ただし, $\phi_{m}=i \gamma \phi_{m}^{*}, \Phi_{m}=i \gamma \Phi_{m}^{*}$ と置いた. $\phi_{m}^{*}, \psi_{m}, \Psi_{m}$ ， $\Phi_{m}^{*}, \Theta_{m}$ は $\gamma$ に対してすべて偶関数となる. このこと を考慮して Fourier 逆変換 (16)を適用すれば, 変位, 応 力はすべて実数，しかも $0 \leq \gamma<\infty$ の範囲で定義される.

$$
\left[\begin{array}{c}
u \\
w \\
\sigma_{\eta \eta} \\
\sigma_{\eta \xi} \\
\sigma_{\xi \xi}
\end{array}\right]=-\frac{P_{0}}{\pi} \int_{0}^{\infty} \sum_{m=1}^{\infty}\left[\begin{array}{c}
\phi_{m}^{*}(\eta) I_{m}(\tau) \\
\psi_{m}(\eta) J_{m}(\tau) \\
\Psi_{m}(\eta) J_{m}(\tau) \\
\Phi_{m}^{*}(\eta) I_{m}(\tau) \\
\Theta_{m}(\eta) J_{m}(\tau)
\end{array}\right] d \gamma
$$

ここに, $I_{m}, J_{m}$ は

$$
\begin{aligned}
& I_{m}(\tau)=\gamma\left[K_{m}^{e}(\tau) \sin \gamma\left(\bar{\xi}_{0}-\xi\right)-K_{m}^{o}(\tau) \cos \gamma\left(\bar{\xi}_{0}-\xi\right)\right], \\
& J_{m}(\tau)=K_{m}^{e}(\tau) \cos \gamma\left(\bar{\xi}_{0}-\xi\right)+K_{m}^{o}(\tau) \sin \gamma\left(\bar{\xi}_{0}-\xi\right)
\end{aligned}
$$

\section{7. 数值計算例および考察}

数値計算では, 簡単のため $b$ を

$$
b=\lambda / \mu=1
$$

とし, $k_{\xi}, k_{\eta}$ の值を

$$
\left.\begin{array}{ll}
\text { (A) } k_{\xi}=0.1, & k_{\eta}=1 \\
\text { (B) } k_{\xi}=10, & k_{\eta}=10000
\end{array}\right\}
$$

とした 2 種類について行う. $k_{\xi}, k_{\eta}$ の数值は実際の基 礎地盤とは直接関係なく，一つの例として選んだ值で ある. 式(13)で示すように, $k_{\xi}, k_{\eta}$ は厚さ $h$ に依存す るものの, 厚板の弾性係数 $\mu$ を基準にした無次元量で あり，(A) は極めて軟らかい基礎，(B) は硬い基礎を想 定した. 集中荷重 $P_{0}$ はすべて静止している厚板表面の 座標原点 $(\xi=0, \eta=0)$ に瞹時に載荷し, 直ちに定速度 $c$ で移動する. したがって, 式 (21) の初期作用点 $\bar{\xi}_{0}$ は

$$
\bar{\xi}_{0}=0 \text {. }
$$

因-2は円振動数の分散曲線で, $\gamma$ に依存した固有値 方程式 (53)の根 $\omega_{m}$ である. ただし, $\gamma=25, m=7$ 次ま で示した. なお, 図中の $V_{R}=0.9194$ は $b=1$ としたと きの Rayleigh 波の伝播速度である. (A) の分散曲線は, $\gamma=0$ 付近では (B) の值より小さく, $\gamma$ が順次増えるに したがって $\omega_{1}$ 以外は一旦 $V_{L}=\sqrt{3}$ に渐近し, さらに 増加すると $\omega_{1}, \omega_{2}$ は $V_{R}$ に渐近し，他のあのは $V_{T}=1$ に渐近する形態をとる. これに対して, (B) では $\omega_{1}$ の みが $V_{R}$ に渐近し，他は $V_{T}$ に渐近する形態となる，い ずれの場合す $V_{L}$ に渐近した後は両者ほぼ同じ形態を 表し, その值は約 $V_{\boldsymbol{R}}$ より大きい。

Miklowitz ${ }^{21)}$ は㓮体滑面上の厚板の問題に対し，そ の固有值方程式 ( Rayleigh-Lamb の振動方程式) の根 を明らかにしている. その根は実数であり, 波長に対す る振動数として表されている. 式 (53) の固有値方程式 は, 基礎弾性係数を $k_{\xi} \rightarrow 0, k_{\eta} \rightarrow \infty$ と極限操作すると, 剛体滑面上の厚板の固有值方程式に合致する。これを 踏まえて, 図-2 (B) で示した $k_{\xi}=10, k_{\eta}=10000$ の数 値計算結果を考察すると, 剛体滑面上の厚板の固有値 方程式の根とほほ同じ形態となり，解 $\phi_{m}, \psi_{m}$ の妥当性 を調べることができる.

図-4は， $P_{0}$ が移動せずその場に固定 $(c=0)$ された とき, 注目点 $(\xi=0.5, \eta=0.5)$ における $\sigma_{\eta \eta}, \sigma_{\xi \xi}$ の応 答である. まず最初に, 時刻 $\tau=\tau_{L}^{\wedge}$ のとき, 応力がお よそゼロの静止から急激に立ち上がり振幅の大きい尖 頭波となって現れる. つづいて, $\tau=\tau_{T}^{\wedge}$ であ応力の急変 がみられる. さらに $\tau=\tau_{L}^{j}(j=B, C, \ldots, G)$ であ顕著 な尖頭波が現れ，応力の急变が観察できる. 全体的に $\sigma_{\eta \eta}$ の応答の方が $\sigma_{\xi \xi}$ より振幅が大きく鋭い形態とな る. また，およそ $\tau=\tau_{\boldsymbol{L}}^{D}$ 以後から約 0.577 の等間隔で 縦波による振幅の大きい尖頭波が現れる.

記号 $\tau_{k}^{j}$ は, 載荷点で誘発された波動が放射状に伝 播し，その波面が注目点に到達した時間を表するので, 


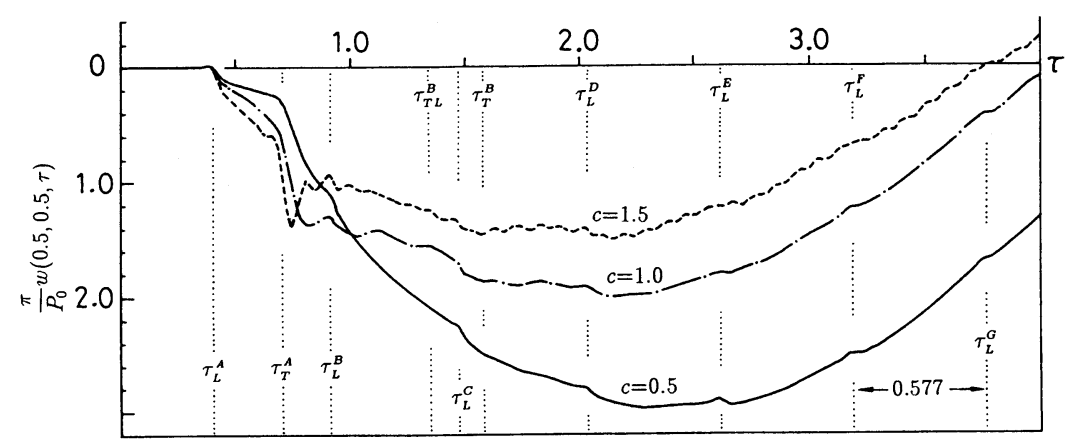

(A) $k_{\xi}=0.1, k_{\eta}=1$

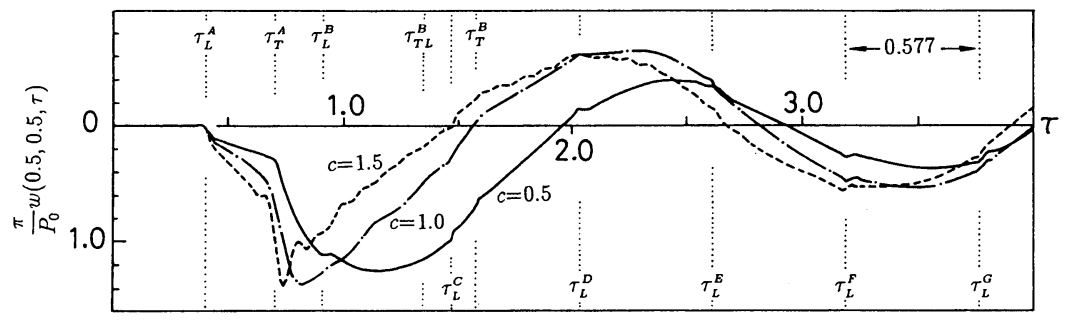

(B) $k_{\xi}=10, k_{\eta}=10000$

园-5 $c=0.5,1.0,1.5$ とした $w(0.5,0.5, \tau)$ の応答
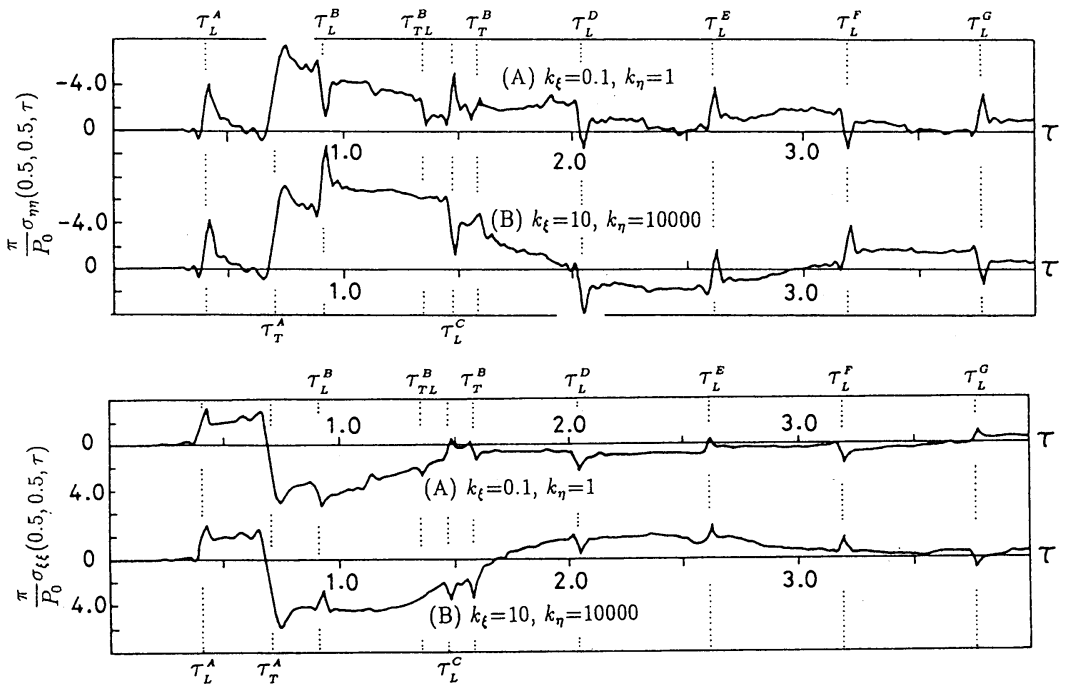

目-6 $c=0.5$ とした $\sigma_{\eta \eta}(0.5,0.5, \tau), \sigma_{\xi \xi}(0.5,0.5, \tau)$ の応答

肩文字 $j=A, B, \ldots, G$ は図-3で示す波動の伝播経路で あり, $A$ は載荷点から誘発された波動が直線的に伝播 して注目点に到達した直接到達経路， $B$ は底面で 1 回 反射, $C$ は底面と上面の 2 回反射して注目点に到達し
た反射到達経路を表す.さらに, $D, E, F, G$ は図-3 に示してないが, 3, 4, 5, 6 回反射する経路を表す. 添 字 $k=L, T$ は波動の伝播速度を表し, 経路を $L$ は縦波 伝播速度 $V_{L}=\sqrt{3}, T$ は横波伝播速度 $V_{T}=1$ で到達する 

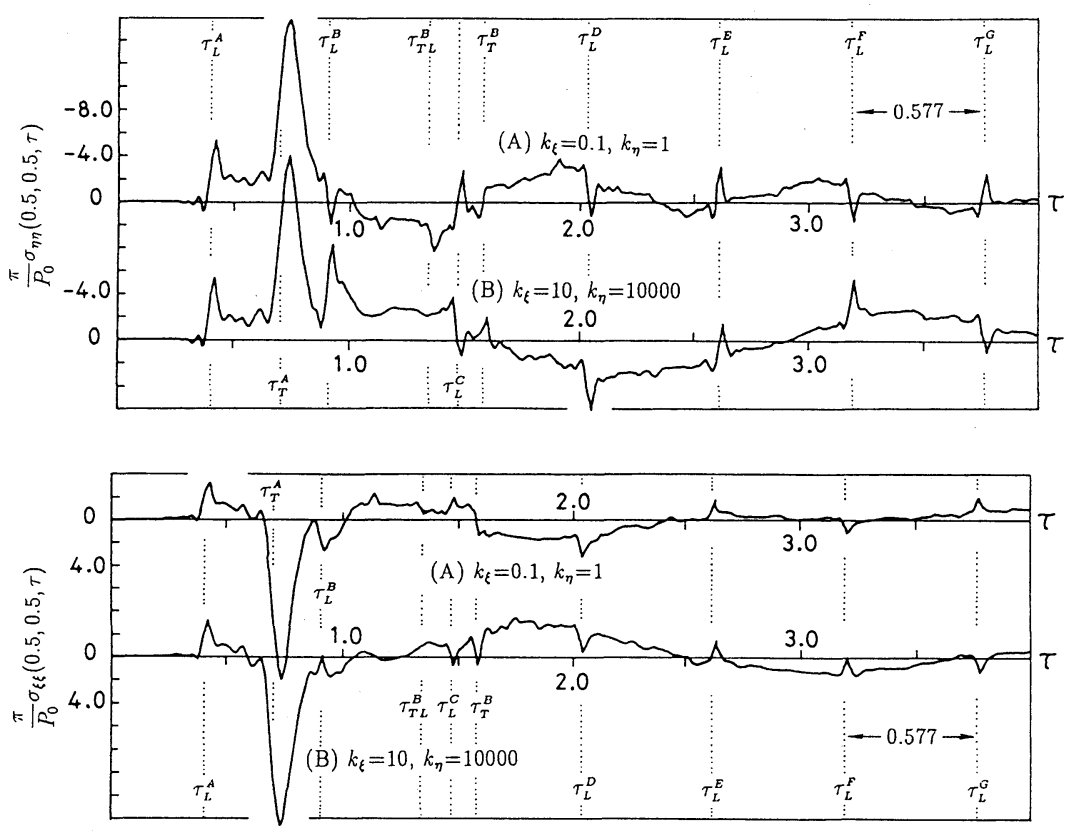

四-7 $c=1.0$ とした $\sigma_{\eta \eta}(0.5,0.5, \tau), \sigma_{\xi \xi}(0.5,0.5, \tau)$ の応答

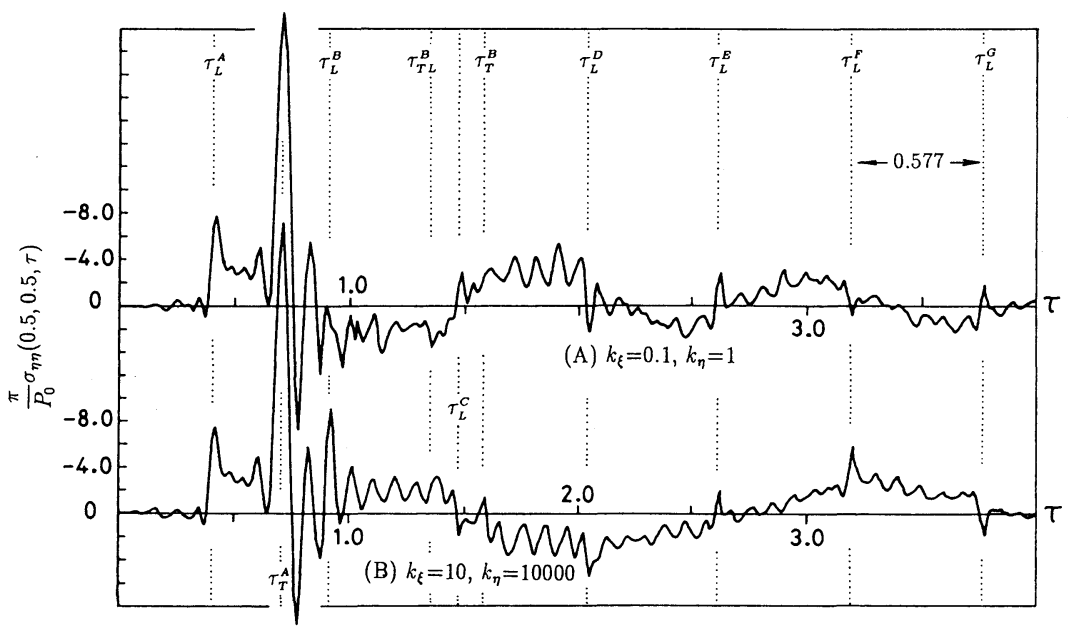

凶-8 $c=1.5$ とした $\sigma_{\eta \eta}(0.5,0.5, \tau)$ の応答

ことを意味する. したがって， $\tau_{k}^{j}$ は

$$
\begin{array}{ll}
\tau_{L}^{A}=0.408 & \tau_{T}^{A}=0.707 \\
\tau_{L}^{B}=0.913 & \tau_{T}^{B}=1.581 \\
\tau_{L}^{C}=1.472 & \\
\tau_{L}^{D}=2.041 \\
\tau_{L}^{E}=2.614 \\
\tau_{L}^{F}=3.189 \\
\tau_{L}^{G}=3.764
\end{array}
$$

となる. 図-3の反射点 $\xi=\xi_{k}(k=1,2,3)$ は幾何学的に 求められ，それぞれ $\xi_{1}=0.333, \xi_{2}=0.2, \xi_{3}=0.4$ となる. 高回反射の経路については, 反射回数 $n$ を基準にとる と, その伝播経路長 $l$ は次式

$$
l=0.5 s \sqrt{1 / s^{2}+1}, \quad s=2 n+1
$$

で得られ, 反射回数 $n$ と $n-1$ による経路差は厚板の無 次元厚さ 1 に渐近する. この結果によって, 長時間経過 して到達する縦波の高回反射の波動は約 $1 / \sqrt{3}=0.577$ 


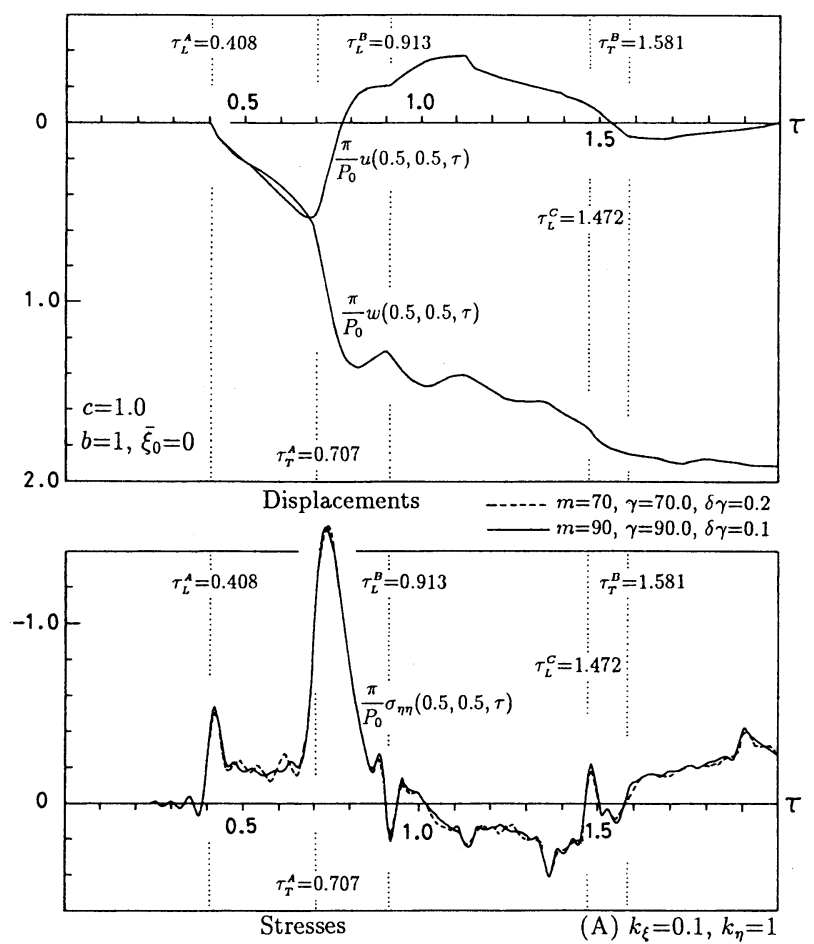

园-9 変位 $u(0.5,0.5, \tau), w(0.5,0.5, \tau)$, 応力 $\sigma_{\eta \eta}(0.5,0.5, \tau)$ の応答，およびその解の収束性

の間隔で尖頭波が現れることになる.

一方, 時刻 $\tau=\tau_{T L}^{B}$ であ応力の急変が見られる. (A) のデータでは顕著である， $\tau_{T L}^{B}$ は厚板底面で 1 回反射 する $B$ 経路に似ており, 載荷点から $\eta=1$ までの距離 を横波伝播速度で, 反射後は縦波伝播速度で注目点に 到達した時間である.この場合, 底面での入射角と反 射角は等しくなく, 反射点は光学 Snell の法則 ${ }^{3)}$ から 求められ， $\xi_{1}=0.259$ となる. それ故，この到達時間は 次式となる。

$$
\tau_{T L}^{B}=1.353
$$

図一5は移動速度を $c=0.5,1.0,1.5$ と変化させた場 合, 注目点 $(\xi=0.5, \eta=0.5)$ の鈶直変位 $w$ の厄答であ る. $c=0.5$ は集中荷重の移動速度が Rayleigh 波より遅 く, $c=1.0$ は横波伝播速度に等しく, $c=1.5$ は横波伝播 速度より速く，縦波伝播速度より遅いことを表す. (A) の軟らかい基礎上の厚板では, 荷重の衝擊的負荷によっ て載荷点で生じた波動が注目点に到達する時刻 $\tau=\tau_{\boldsymbol{L}}^{\boldsymbol{\Lambda}}$ から変形が始まる. 以後, 速度が羊い $c=0.5$ の場合で は, $\tau=\tau_{T}^{\wedge}$ からゆったりとした㓮体变位的な挙動を伴っ て厚板全体が振幅の大きい曲げたわみを示す. 速度が速 い $c=1.5$ では, 時刻 $\tau=0.333$ で注目点の真上 $(\xi=0.5)$ の厚板表面に $P_{0}$ が到達し通過するが, しかし, この時 刻で変位が生じなく， $\tau=\tau_{\boldsymbol{L}}^{\wedge}$ から変形が始まる， $\tau=\tau_{\boldsymbol{T}}^{\wedge}$ で尖頭的な変位を生じ, 以後ゆったりとした変形を伴
い, その振幅は $c=0.5$ の場合より小さい.これに対し て, (B) の硬い基礎上の厚板の応答は, $\tau=\tau_{T}^{\wedge}$ まで (A) と同じ挙動を示すが, 以後 $w=0$ を中心とした振動形態 を示す.

図一6 $c=0.5$ とした $\sigma_{\eta \eta}(0.5,0.5, \tau), \sigma_{\xi \xi}(0.5,0.5, \tau)$ の応答である. $\tau=\tau_{T}^{\wedge}$ から $\tau=\tau_{T}^{B}$ までの振幅がいくら か助長され大きくなるものの, $c=0$ の場合に似た応答 形態となる.

図一7は $c=1.0$ とした $\sigma_{\eta \eta}(0.5,0.5, \tau), \sigma_{\xi \xi}(0.5,0.5, \tau)$ の応答である.この場合は, 集中荷重が横波伝播速度 で厚板表面を移動し, 注目点の真上 $\xi=0.5$ にいち早く 到達し, 続いて, 横波伝播速度の波面が注目点に到達 することにより， $\tau=\tau_{T}^{\wedge}$ では刺激され振幅の大きい鋭い 尖頭波となって現れる.

図-8は $c=1.5$ とした $\sigma_{\eta \eta}(0.5,0.5, \tau)$ の応答である. この場合, 集中荷重の移動速度が横波伝播速度より速 く, 縱波より遅いことにより， $\tau=\tau_{L}^{\wedge}$ と $\tau=\tau_{T}^{\wedge}$ の両方 の尖頭波に刺激を与え，とくに， $\tau=\tau_{\boldsymbol{r}}^{\wedge}$ 振幅が極端に大 きく助長され, 鋭い尖頭波となって現れる. また, 荷重 が注目点の真上を通過した後は激しい振動形態となる。

集中荷重か瞬時に衝擊的に負荷され, 直ちに定速度 で厚板表面を移動する場合, 載荷点で誘発された波動 が注目点に到達する時刻と, 注目点の真上の厚板表面 に荷重が到達する時刻が短い時間差で重なると, その 


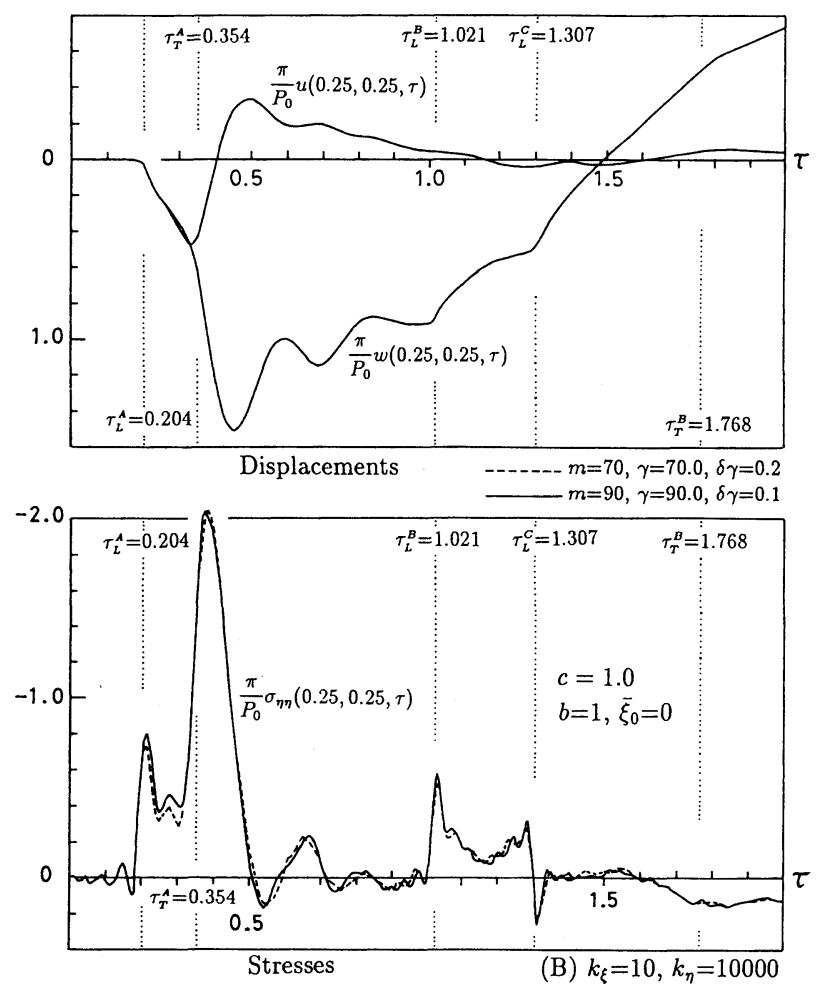

国-10 変位 $u(0.25,0.25, \tau), w(0.25,0.25, \tau)$, 応力 $\sigma_{\eta \eta}(0.25,0.25, \tau)$ の応答，およひその解の収束性

ときの応力は刺激され振幅が助長された鋭い尖頭波と なる. $c=1.0,1.5$ とした応答では, 第 1 波の到達時刻 $\tau=\tau_{\boldsymbol{L}}^{\wedge}$ であ起こるが，とくに，第 2 波の $\tau=\tau_{\boldsymbol{T}}^{\hat{A}}$ で応力 か際だって助長された鋭い尖頭波となって現れる。

集中荷重の衝擊的負荷によって，載荷点を中心とし て応力波が誘発し放射状に伝播する．載荷点から注目 点まではある距離があり, 応力波が最初に注目点へ到 達する時刻 $\tau=\tau_{L}^{\Lambda}$ 以前で応力がは静止のゼロでなくて はならない，図-5の変位はこれを満足するが，しかし， 図-7および図-8では， $\tau=\tau_{\boldsymbol{L}}^{\wedge}$ 以前でいくらか応力が発 生している.これは, 応力がゼロの状態から, 波動の到 達によって不連続的に急激に立ち上がる現象を, 連続 したモード関数の重ね合わせによって表現させようと する解法によるすので， $\tau=\tau_{\boldsymbol{L}}^{\wedge}$ 以前で応力が少し発生 してしまう. しかし， $\tau=\tau_{\boldsymbol{L}}^{\wedge}$ で立ち上がる尖頭波の振幅 や，以後誘発する他の振幅と比較してきわめて小さく， $\tau=\tau_{\boldsymbol{L}}^{\wedge}$ 以前は静止を満たしていると判断してよいであ ろう. また，応力は変位を微分することによって表さ れ，このため応力は $\gamma$ および $\omega_{m}$ に対する収束性が変 位より劣る. この収束性の違いによって $\tau=\tau_{\boldsymbol{L}}^{\wedge}$ 以前で 変位は静止のゼロを表すが, 応力はいくらか発生する.

数値計算では $\gamma$ の皘分上限值を $\gamma=70$, その積分分割
ステップを $\delta \gamma=0.2$, 級数 $m$ の上限次数を $m=70$ まで採 用した. 図-9は注目点を $\xi=\eta=0.5$, 図-10は $\xi=\eta=0.25$ の庆答，ならびにその解の収束性について示したすの で, 上限値は $\gamma=90, m=90$ まで採用, 分割ステップを $\delta \gamma=0.1$ とした解と比較した。变位は完全に合致するの に対して，応力はいくらかの差が現れるが，両者の間 で極端な相違がみられず，ほぼ合致した解を得たと判 断してよいであろう。これによって解の収束性を確認 した.

\section{8. 結論}

集中衝撃移動荷重を受ける Winkler 弾性基礎上厚 板の過渡現象問題を精密に解析することができた。本 研究の結論は次の通りである.

(1) Fourier 変換ならびに固有関数展開を用いるこ とにより，連立偏微分方程式で表された運動方程式が 境界条件，初期条件のもとで直接的に，しかす精密に 解かれる解法を提示することができた. Fourier 変換を 導入することにより, 形式的に運動方程式が複素数の かたちとなるが, 固有値方程式の根が複素根とならず, すべて実数の範囲で問題が解決される. また, 弾性体の 振動方程式の解を基とした固有関数を使うため，関数 
の直交性など，よく知られた関係を使うことができる.

（2）基礎弾性係数 $\left(k_{\xi}, k_{\eta}\right)$ に対する $\gamma$ に依存する円 振動数の分散曲線を得ることができた. 基礎弾性係数 の值によって分散曲線は変化するが, およそ Rayleigh 波の伝播速度より速い範囲で現れる.

（3）集中荷重が衝擊的に負荷され移動せずその場に 固定 $(c=0)$ された場合, 載荷点から少し離れた一空間 点の応答は, 静止の状態から綐波面の直接到達によっ てはじめの擾乱が起こり，続いて伝播速度の遅い波の 到達，さらには境界からの反射波の到達によって摄乱 が現れ，初期の複雑な過渡波動伝播の現象を明らかに することができた. さらに時間が経過したとき，高回 反射の縦波のみによる擾乱がお゙よそ 0.577 の間隔で起 こる.

（4）集中衝撃移動荷重では, 基礎弾性係数, ならび に荷重の移動速度の違いによる複雑な過渡波動伝播形 態を明らかにすることができた. (A), (B) のデータに 対して, 変位は際だって異なる応答となるのに対して, 応力では大きな差が現れなかった。 また，集中荷重の 移動速度が速くなるに従って，振幅が大きく鋭い尖頭 波となる.とくに，横波伝播速度より速い $c=1.0,1.5$ では, $\tau=\tau_{\boldsymbol{T}}^{\wedge}$ の振幅が極めて大きく助長され鋭い尖頭 波を表す。

\section{参考文献}

1) 北村泰寿, 桜井春輔: 彈性基礎上の 4 辺自由板の极数解, 土木学会誌, pp. $61-66,1979$ 年 3 月.

2) Jaiswal, O. R., and Iyngar, R. N.: Dynamic response of a beam on elastic foundation of finite depth under a moving force, Acta Mechanica, Vol. 96, pp. 67-83, 1993.

3) Ewing, W. M., Jardetzky, W. S., and Press, F.: Elastic Waves in Layered Media, McGraw-Hill Book Company, inc., New York, 1957.

4) Lamb, H.: On the propagation of tremors over the surface of an elastic solid, Phil. Trans. Roy. Soc. London, Ser. A, 203, pp. 1-42, 1904.

5) Sneddon, I.: Fourier Transforms, McGraw-Hill, New York, pp. 447-449, 1951.
6) Cole, J., and Huth, J.: Stresses produced in a halfplane by moving loads, J. Appl. Mech., Vol. 25, ASME, pp. 433-436, 1958.

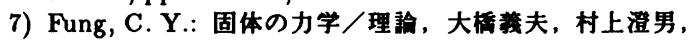
神谷粑生 共訳, 培風館, 1970 .

8) Gakenheimer, D. C., and Miklowitz, J.: Transient excitation of an elastic half space by a point load traveling on the surface, J. Appl. Mech., Vol. 36, pp. 505-515, 1969.

9) Sandler, I. S., and Bleich, H. H.: Stresses in an elastic half space due to surface loads progressing at the speed of Rayleigh waves, J. Appl. Mech., pp. 372-377, 1972.

10）小林治伐, 国田恵一郎, 鹿岛光洋: 単杶支持された埇・ コンクリート合成梁の弹性簿曾応答解析, 榑造工学詥文 葉, Vol. 38A, pp. 1489-1496, 1992 年 3 月.

11）小林治传, 園田恵一郎, 石丸和宏 : 隔・コンクリート合 成円版の弾性渻答解析, 梅造工学詥文集, Vol. 38A, pp. 1497-1504, 1992 年 3 月.

12）小林治传, 舆田東吾, 園田恵一郎: 跑鳌荷重を受ける単純 支持はりの応力波伝播解析, 槽造工学論文集, Vol. 38A, pp. 1505-1514, 1992 年 3 月.

13) 石川清志: Voigt 型粘弹性体繁限带板の過渡応力波伝播, 土木学会詥文集，第 380 号/I-7, pp. 273-281, 1987 年 4 月.

14）石川清志, 夏目正太郎：集中渻菏重を受ける軸対称 Voigt 型粘倠性展体の遗渡応力波伝播，土木学会詥文集， 第 422 号/I-14, pp. 275-284, 1990 年 10 月.

15) Achenbach, J. D.: Wave Propagation in Elastic Solids, North-Holland, New York, 1973.

16) Miklowitz, J.: The Theory of Elastic Waves and Waveguides, North-Holland, New York, 1978.

17) Hetenyi, M.: Beams on Elastic Foundation, Ann Arbor: The University of Mechigan Press, 1946.

18）西村源六郎：振動工学, 誠文堂新光社, 1969.

19) 小平吉男 : 物理数学, 第二卷, 文献社, 1971.

20) Dolph, C. L.: On the Timoshenko theory of transverse beam vibrations, Quart. Appl. Math., Vol. XII, No. 2, pp. 175-187, 1954.

21) Miklowitz, J.: Transient compressional waves in an infinite elastic plate or elastic layer overlying a rigid half-space, J. Appl. Mech., Vol. 29, No. 1, pp. 53-60, 1962.

(1995. 1. 23 受付)

\title{
TRANSIENT WAVES IN AN INFINITE THICK PLATE ON ELASTIC FOUNDATION SUBJECTED TO CONCENTRATED MOVING LOADS
}

\author{
Kiyoshi ISHIKAWA, Teruhiko YODA and Masaharu HIRASHIMA
}

\begin{abstract}
A method of analysis for the solutions of transient wave propagation in an infinite thick plate on elastic foundation is developed in terms of eigenfunctions depending on the Fourier integral transforms. The Winkler assumption that the reaction forces of the foundation are proportional at every point to the bottom bounding displacements of the plate touching the foundation is taken here. The time history of displacements and stresses representing the head of the disturbance are evaluated as transient wave propagation corresponding to different speeds of concentrated moving loads that are suddenly applied at the free surface of the plate standing still initially.
\end{abstract}

